\title{
Assessing the Degradation Effects of Local Residents on Urban Forests in Ontario, Canada
}

\author{
Wendy McWilliam, Paul Eagles, Mark Seasons, and Robert Brown
}

\begin{abstract}
Urban forests provide essential social, ecological, and economic functions in support of their communities; however, surveys indicate adjacent residents conduct activities within their yards and the adjacent public forest edge that degrade these systems. Local governments rely on boundary-focused passive management and/or active management to limit impacts. Encroachment results from various boundary treatments; however, it is not known whether encroachment represents a substantial source of degradation within Ontario, Canada, municipal forests. To evaluate this, percentage cover of encroachment impacts adjacent to 186 homes within 40 forests of six Southern Ontario municipalities was surveyed. The results indicated degradation resulting from encroachment was substantial. Encroachment occurred in highly valued and sensitive ecosystems, and during sensitive time periods. This was highly prevalent and covered a substantial proportion of the forest edge. Some encroachment behaviors were particularly harmful, resulting in the loss of significant forest area to residential land uses. Furthermore, encroachments remained over long periods. The small sizes and convoluted shapes of urban forests leave them vulnerable to these impacts. Prevailing municipal strategies are insufficient to protect these systems from encroachment. To ensure their long term protection, municipalities and their communities need to substantially increase their commitment and resources for addressing encroachment.

Key Words. Adjacent Land Use; Green Infrastructure; Greenspaces; Planning and Management; Residential Encroachment; Urban Forest Ecosystems; Urban Forest Edges.
\end{abstract}

Urban forest ecosystems provide essential ecological and social services to human communities. They provide stormwater management (Correll 1999), filter air-borne pollutants (Scott et al. 1999), reduce the rate of climate change (Nowak and Crane 2002), and moderate extreme weather conditions, improving human thermal comfort (Brown and Gillespie 1995). Furthermore, these ecosystems provide key recreation facilities in support of human health (Kaplan 1995).

Many studies have looked at the impacts of human activities, and housing areas in general, on urban forests. Key impacts include reductions in soil organism diversity and soil fertility (MalmivaaraLamsa and Fritze 2003), and local and regional native vegetation diversity resulting from human trampling of soils and vegetation (Florgard 2000; Murphy 2006). Reductions in local and regional native wildlife diversity resulting from human disturbance and wildlife habitat alteration may also occur (Friesen et al. 1995; Jokimaki and Huhta 2000). Furthermore, the recreational experiences of these areas are degraded through the proliferation of litter, tree and plant damage, fire rings, and unauthorized trail creation (Lynn and Brown 2003). Residential encroachment refers to the impacts on natural areas resulting from adjacent resident activities within their yards and in the forest edge. Some studies indicate encroachment results in impacts similar to those occurring with recreationrelated activities (Matlack 1993; McWilliam 2009); however, other impacts are unique and more serious, such as the loss of public forest edge to private residential land uses (McWilliam 2009).

Because of the similarity between impacts of recreation and encroachment, recreation ecology theory regarding factors determining their significance can be loosely applied. Recreation ecology studies indicate the significance of human activity impact is determined by the impact characteristics (its areal extent, longevity, and its intensity of impact), and the ecosystem attributes (i.e., the human value placed on the ecosystem) (Cole 2003). Intensity of impact is in turn determined by the frequency and type of use, how it occurs, the season in which it occurs, and the ecosystem sensitivity (Cole 2003).

Progress has been made in defining factors that determine the significance of residential encroachment within urban forests. In terms of intensity, studies have identified the types of encroachment. For example, Matlack (1993) surveyed 14 types, and McWilliam et. al. (2010) surveyed 20 farthest from forest borders. Types reflected waste disposal, yard extension, unauthorized forest recreation activities, invasive yard plant extensions, as well as behaviors in reaction to forest encroachment into residential yards (e.g., removal of forest border vegetation over-arching residential yards) (McWilliam et al. 2010). Encroachment studies within Southern Ontario have taken place in mixed, and particularly deciduous, urban forests (Taylor 1992; Ouellet 1996; McWilliam 2009), and publicly-owned mown grass strips lying between residential property lines and forest borders (McWilliam et al. 2010). Forested ecosystems, particularly deciduous forests, are among the more sensitive ecosystems to human activity impacts because of their sensitive ground floras (Kuss and Hall 1991). Little is known about why encroachment activities occur, or the frequency at which residents perform them. 
In terms of areal extent, studies indicate residential encroachment impacts are concentrated within forest edges rather than uniformly distributed in the forest (Matlack 1993; McWilliam et. al. 2010). Matlack (1993) surveyed 95\% of both yard and recreation related impacts within $67 \mathrm{~m}$ of forest borders within forests without internal roads; while McWilliam et al. (2010) surveyed $95 \%$ of residential impacts within $34 \mathrm{~m}$ within forests abutting contiguous single-family housing (with gross densities of 5 to 19 houses per hectare). However, the area of the forest floor covered by encroachment within this distance within Southern Ontario municipalities is unknown.

According to boundary theory, the condition of the boundary of a natural system indicates its overall health (Schonewald-Cox 1988). Thus, it is important to retain its integrity to protect the more sensitive features and functions occurring within the forest interior. According to Schonewald-Cox (1988), the extent to which an ecosystem boundary is protected from adjacent land use impacts is dependent on: 1) efficacy of its natural filters (e.g., a closed side canopy reduces the extent of edge generated by a change in microclimate between a forest and open field, and is therefore a natural filter for limiting microclimatic impacts); 2) efficacy of humangenerated filters (e.g., fences for limiting encroachment impacts); 3) extent to which filters are upheld (e.g., through encroachment bylaw enforcement); 4) similarity between adjacent ecosystems, and 5) similarity between land use values and objectives of adjacent landowners. Schonewald-Cox (1988) argues that a loss of, or reduction in, one of these factors will require an increase of those remaining if the integrity of the boundary, and therefore the natural system, is to be protected through time. Otherwise, features and functions of the boundary, and therefore the ecosystem, will change to become more similar to those of the adjacent land use.

Ontario governments have developed planning and management policies and practices in support of their urban forested ecosystems to ensure their long-term protection. While Ontario municipal planners and managers recognize that impacts will occur with adjacent development, they want to ensure impacts are kept to acceptable limits (McWilliam 2009). To accomplish this, municipal planners and managers rely on boundary-focused, passive management measures, such as fences, and/or active management measures, such as boundary monitoring, bylaw enforcement, and resident education (McWilliam 2009). Some planners and managers recognize encroachment occurs with this strategy; however, they do not know whether it is substantial enough to warrant changing, or increasing resources or strategies (McWilliam 2009).

The goal of this paper was to assess the degradation effects of encroachment within Ontario urban forest edges. This was accomplished by determining the area of the forest floor affected by adjacent residents' encroachment activities.

\section{METHODS}

\section{Study Areas}

Human impacts were sampled behind 186 residential properties within 40 forest fragments in six municipalities of Southern Ontario, including Cambridge, Guelph, Kitchener, Mississauga, Oakville, and Waterloo. Municipalities range in population between 100,000 to 700,000 and are in the Greater Toronto Area (Figure 1). All of these municipalities are implementing boundary treatments as passive management in some forests and/

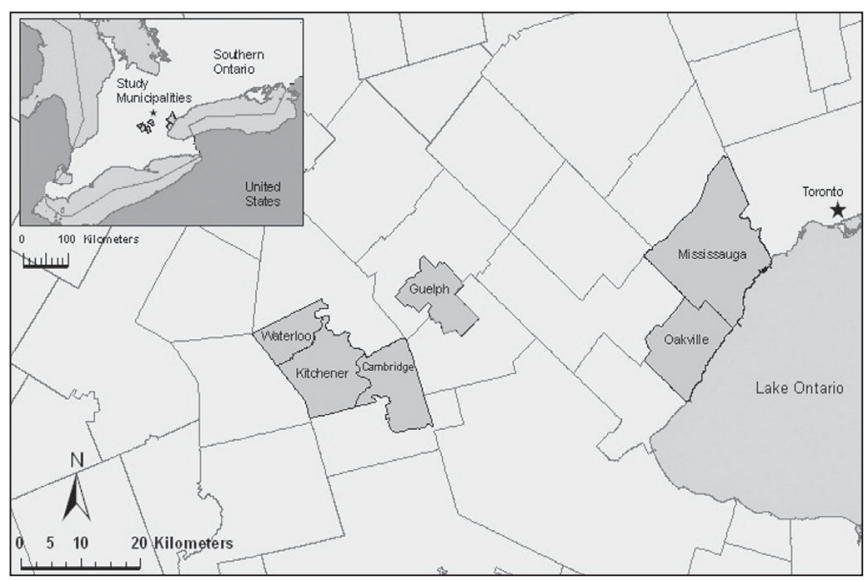

Figure 1. Study municipalities in Ontario, Canada. Image courtesy of the Ontario Ministry of Natural Resources (2002).

or active management that may include boundary monitoring, bylaw enforcement, or resident education (McWilliam 2009)

Most study forests were remnants of deciduous, but a few were mixed, eastern forest patches or corridors. They ranged in size between 1 and 50 hectares in area, without internal roads, and had minimum widths of $20 \mathrm{~m}$. However, if there was development on the opposing side of the forest, then the minimum width was $40 \mathrm{~m}$. This reduced the risk of sampling opposing resident encroachment and responds to results of a pilot study (McWilliam 2009) indicating a majority of encroachment occurred within $20 \mathrm{~m}$ of forest borders. To avoid overlapping human activity impacts associated with community recreation, authorized recreational trails had to be located a minimum of five meters away from study areas. Research indicates the area of impact associated with recreational trail use is approximately five meters from trail edges (Cole 1987). Sites adjacent to park entry points were not sampled to avoid sampling of encroachment arriving from other residences in the community.

Forest borders were without significant natural barriers that could serve as natural filters to encroachment (e.g., steep slopes, poorly drained soils). Abutting housing was typical of post World War II housing within Southern Ontario, consisting of singlefamily, contiguous and detached, or semi-detached, with backyards. Gross housing densities were between 5 and 19 houses per hectare. Housing was at least 10-years-old. Recreation ecology research indicated maximum impacts of recreational activities occurred in forests within two to five years of their commencement (Cole 1987). Back yards were between 10 and 40 meters in width.

\section{Sampling Methods}

The frequency and percentage area of the forest floor covered by encroachment activities were sampled using a quadrat/transect sampling method. The use of quadrats and transects are commonly used to sample forest vegetation (Kent and Coker 1992). Recreation ecology research commonly measures recreational trampling impacts on vegetation communities using this method (For example, Cole \& Marion 1988). The quadrat/transect sampling method requires the researcher to visually estimate the percentage of a sample area occupied by components of the forest floor. In urban forest edges, component categories include native, naturally occurring elements (such as native plants, soils, or woody debris), 
exotic vegetation (arriving via means other than encroachment), and encroachment elements (e.g., waste, lawn extensions, unauthorized pathways, or invasive yard plants). Within each $0.5 \mathrm{~m} \times$ $0.5 \mathrm{~m}$ quadrat sampled, the authors of the current study recorded the percentage cover of the quadrat of each of these components visible at $30 \mathrm{~cm}$ above the ground, according to the Braun-Blanquet (1932) cover-abundance scale. The scale assigns a number, or code, to each forest floor component, ranging from 0 to 6 (Table 1).

Table 1. Braun-Blanquet (1932) abundance-cover scale.

\begin{tabular}{ll}
\hline Code & Scale \\
\hline 0 & $0 \%$ \\
1 & $<1 \%$ \\
2 & $1 \%-5 \%$ \\
3 & $6 \%-25 \%$ \\
4 & $26 \%-50 \%$ \\
5 & $51 \%-75 \%$ \\
6 & $76 \%-100 \%$ \\
\hline
\end{tabular}

The frequency in which encroachment occurred was calculated by counting the number of times one type of encroachment appeared within the quadrat, no matter what percentage of the quadrat it covered.

The sample design was perfected during the pilot study to capture the breath and depth of encroachment activities under different boundary treatments prevalent in Ontario (McWilliam 2009). Boundary treatments included: no boundary treatment; municipal boundary post; mown grass strip; mown grass strip and path; and fence, fence with mown grass strip, fence with mown grass strip and path, fence with gate, fence with gate and mown grass strip, and fence with mown grass strip and path.

Eleven $0.5 \mathrm{~m} \times 0.5 \mathrm{~m}$ quadrats were sampled at two-meter intervals along five transects placed perpendicular to, and equal distance along, property boundaries. From the property boundary, transects extended $20 \mathrm{~m}$ into forest edges. The $20 \mathrm{~m}$ transect length was developed from the results of the pilot study that indicated the majority of encroachment occurred within $20 \mathrm{~m}$ of forest borders. The first and last transects were placed one meter from neighboring property boundaries to reduce the risk of recording neighboring encroachment. This design resulted in 55 samples per site, for a total sampling intensity of 930 transects and 10,225 samples (Figure 2).

Care was taken to record only encroachment associated with adjacent study residents. For example, cut trees were not recorded because resident-cut trees could not be distinguished from municipally-cut trees. In addition, evidence of old dumps, rock piles, and old fencing, were not recorded as they may have been from previous agricultural land uses.

Categories of encroachment were developed in order to analyze the significance of different encroachment behaviours within the forest edge. Categories of encroachment were developed from the types and spatial patterns of encroachment in forest edges in relation to yard activities and patterns revealed in the pilot study (McWilliam 2009). Municipal forest managers, bylaw enforcement officers, and casual conversations with residents verified these behaviors.

Behaviors identified include: 1) waste disposal, 2) yard extension, 3) forest-recreation, 4) response to forest encroachment, and 5) yard plant invasions. Disposal behavior results in residence-related waste dumped in forest edges. Yard extension

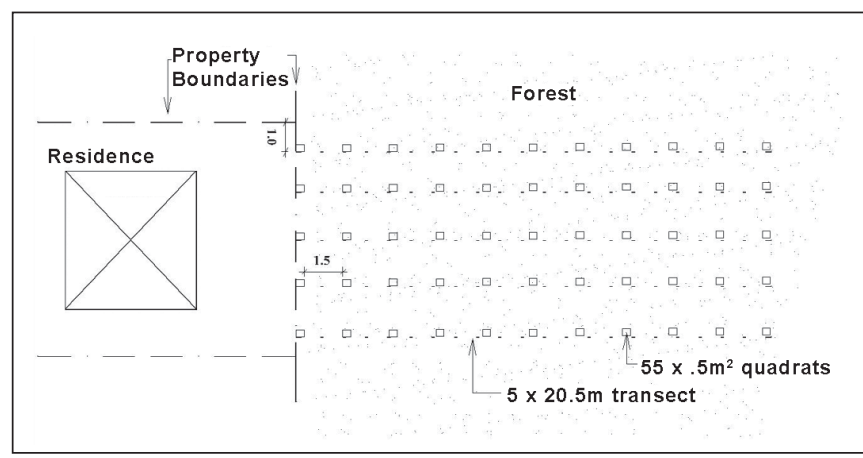

Figure 2. Quadrat/Transect sampling design for one study site.

encroachment includes any extensions of private yard-related land uses within the public forest edge. Forest recreation encroachment includes types of encroachment that result in private, forest recreation-related facilities. Yard plant invasion encroachments result in garden plants growing within the forest edge. Exotic plants growing in the forest edge, but not typically grown in residential gardens, were not included within the encroachment category. Residential encroachment in response to forest encroachment refers to encroachment activities responding to the forest encroaching into yards (e.g., forest vegetation or wildlife).

\section{Data Analysis}

A null hypothesis of uniform distribution within the forest of all encroachment traces, encroachment behaviors, and by boundary treatments was tested using a Kolomogorov-Smirnov test. The number of encroachment areas (frequency) and the percentage of the sampled forest floor covered by each area of encroachment were calculated for all encroachments, as well as by type and behavior of encroachment. In addition, an indicator of the significance (or of the total area covered by encroachment) per site was calculated by multiplying the mean frequency by the mean Braun-Blanquet (1932) abundance cover scale. For example, if a yard extension encroachment trace was sampled three times in a site (i.e., in three different quadrats) and covered a mean of $75 \%$ to $100 \%$ of the quadrats (Braun-Blanquet cover scale of 6), then the indicator of encroachment significance for this site would be 18 .

\section{RESULTS}

What were the prevalence, mean frequency and percentage cover of encroachment types and behaviors?

Evidence, or traces, of encroachment were recorded in 184 of 186, or $99 \%$ of sites. Encroachment incidences numbered 4,422 and were recorded at a mean frequency of approximately 23 traces (evidence of encroachment within quadrats) per study site. Encroachment traces covered on average 26\% to $50 \%$ of the sampled area. Twenty-nine types of encroachment were sampled. Table 2 lists the frequency of encroachment by type and behavior. Encroachment types suggest encroachment activities are closely associated with yard activities, primarily taking place during the growing season, but stretching into the autumn months after leaf drop. The presence of Christmas trees indicates a small amount of encroachment also occurs in winter.

Waste disposal and yard extension were the most commonly recorded encroachment behaviors. Waste disposal types of encroachment accounted for 59\% of encroachment events 
Table 2. Number of encroachment traces recorded within all study sites by type and behavior.

\begin{tabular}{|c|c|c|c|c|c|c|c|c|}
\hline Waste disposal & \# & Yard extension & \# & Forest recreation & $\#$ & $\begin{array}{l}\text { Forest } \\
\text { encroachment }\end{array}$ & \# & $\begin{array}{l}\text { Yard plant } \\
\text { invasions }\end{array}$ \\
\hline Organic debris & 1176 & Lawn extensions & 852 & Illegal paths & 263 & Forest floor removal & 137 & 142 \\
\hline Consumer waste & 716 & Garden extensions & 304 & Forts & 10 & Hacked tree & 8 & \\
\hline Construction waste & 216 & Firewood & 12 & Furniture (in forest) & 5 & & & \\
\hline Granular Material & 192 & Building (including & 12 & Fire pit & 1 & & & \\
\hline Human-placed Rock & 141 & fences) & & & & & & \\
\hline Leaf piles & 65 & Balls & 11 & & & & & \\
\hline Junk & 61 & Swimming pool & 6 & & & & & \\
\hline Grass clippings & 36 & Sport facilities & 2 & & & & & \\
\hline Ash/Charcoal & 15 & & & & & & & \\
\hline Compost bin & 11 & & & & & & & \\
\hline Compost & 8 & & & & & & & \\
\hline Christmas tree & 7 & & & & & & & \\
\hline Pool pipe & 7 & & & & & & & \\
\hline Dog feces & 4 & & & & & & & \\
\hline Visible chemicals & 2 & & & & & & & \\
\hline
\end{tabular}

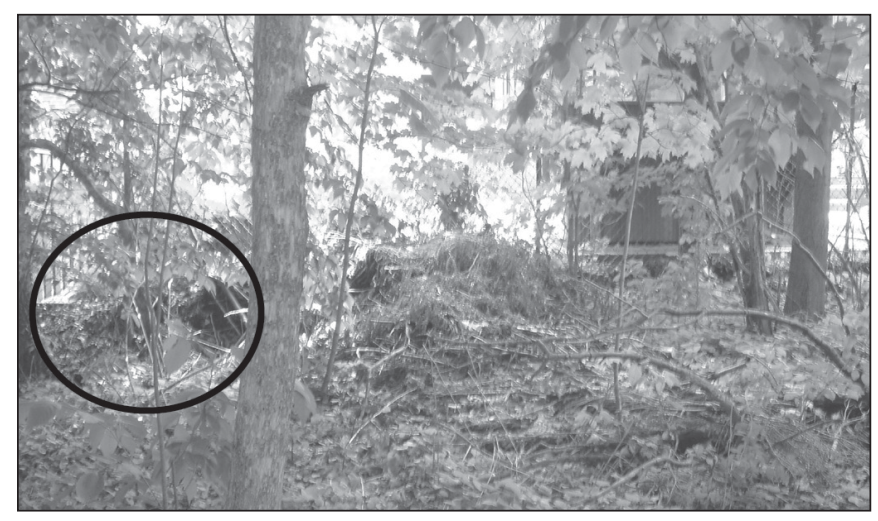

Figure 3. Other organic debris type of waste disposal encroachment. Photograph location: Winston Blvd. Woodlot, Cambridge.

and occurred in $99 \%$ of sites. Types of waste disposal referred to as 'other organic debris' (e.g., branches, discarded plants), 'miscellaneous consumer waste' (e.g., packaging materials), 'construction waste,' and 'granular material' (soil, gravel, etc.) accounted for approximately $86 \%$ of all waste disposal traces. Waste disposal behavior traces covered a mean of $26 \%$ to $50 \%$ of quadrats in which waste disposal was recorded. Figure 3 is a photograph of typical yard-related waste sampled in forest edges. Yard extension encroachment accounted for $27 \%$ of all encroachment occurrences, and was recorded in $44 \%$ of study sites. Lawn extensions (areas of mown grass) and garden extensions (e.g., flower beds, patios), together, accounted for approximately $96 \%$ of these traces. Structure encroachments (including fences) were sampled infrequently; however, they may have been under-sampled. Only $38 \%$ of the study sites had a municipal fence, post, or survey stake indicating the legal property line. The study authors used adjacent boundary markers to locate the boundaries of those sites missing boundary markers; however, sites with ambiguous boundaries were not sampled.

Although yard extensions occurred less frequently than waste disposal encroachments, they covered a greater proportion of their quadrats, occupying a mean of $76 \%$ to $100 \%$. Figure 4 is an example of a typical yard extension.

While forest recreation-related encroachment accounted for only $6 \%$ of encroachment, it was also highly prevalent, occurring

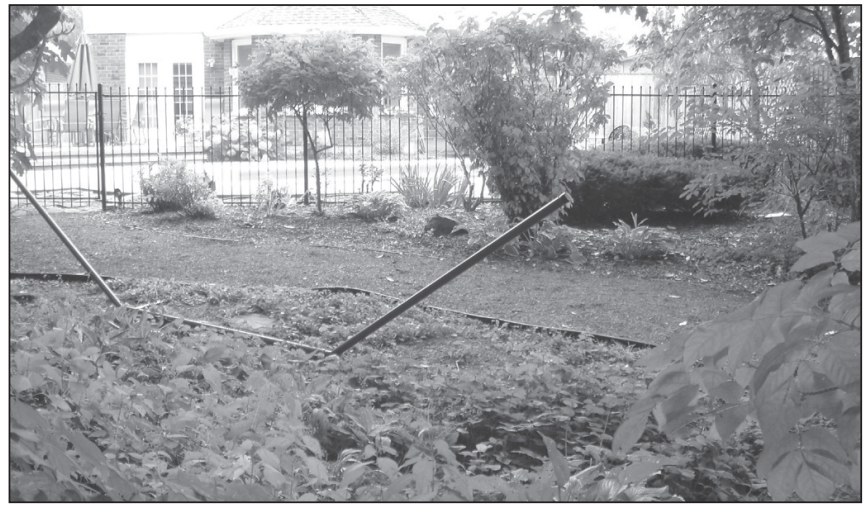

Figure 4. A garden-extension type of yard extension encroachment behavior. Photo location: Monarch Woods, Kitchener.

in $44 \%$ of study sites. Almost $95 \%$ of traces were unauthorized pathways emanating from resident yards (Figure 5). Although this category had a relatively low frequency of encroachment per site (making up only 6\% of all encroachment traces), unauthorized pathways covered a large percentage (76\% to $100 \%)$ of their quadrats.

Encroachment related to invasive yard plants accounted for only $3 \%$ of encroachment traces, but occurred in $24 \%$ of study sites. They covered a mean of $26 \%$ to $50 \%$ of their quadrats. Observations of their patterns, and conversations with residents, indicated that some residents planted garden plants in the forest edge (removing native vegetation) to improve the forest's aesthetic appearance, to increase privacy, or for safety (Figure 6). Observations of growing patterns also indicated invasive yard plants sometimes arrived inadvertently through vegetative growth across residential boundaries, and through waste disposal encroachment.

Forest encroachment accounted for $3 \%$ of traces, and occurred in $12 \%$ of study sites. The removal of forest vegetation constituted $95 \%$ of this encroachment behavior. The mean percentage cover of traces was high, $51 \%$ to $75 \%$ of their quadrats. Figure 7 illustrates resident removal of forest border vegetation.

What was the distribution pattern of encroachment for each and all behaviors of encroachment with distance from forest borders?

The distribution of encroachment impacts, as a group, is determined by the distance from the forest border $(P<0.05)$. 


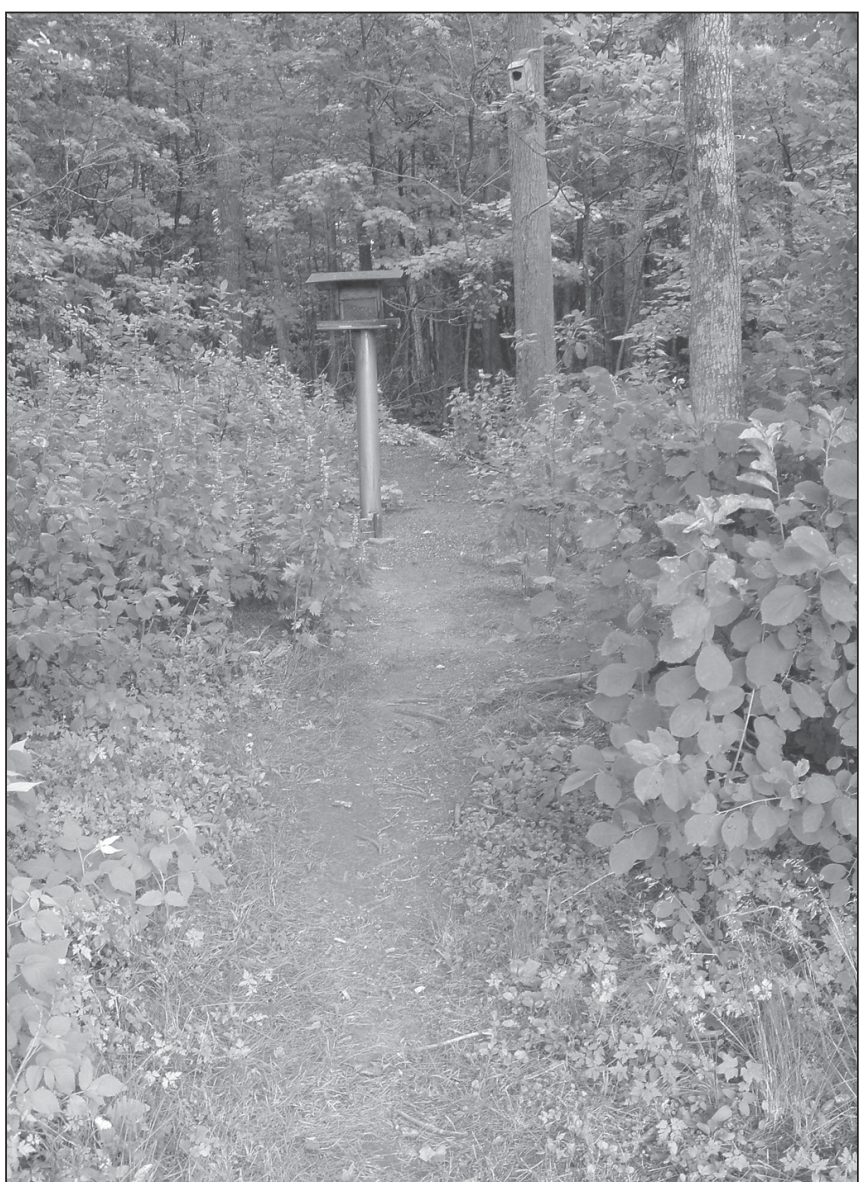

Figure 5. Unauthorized private pathway from a residential yard. Photo location: Sugar Bush Park, Waterloo.

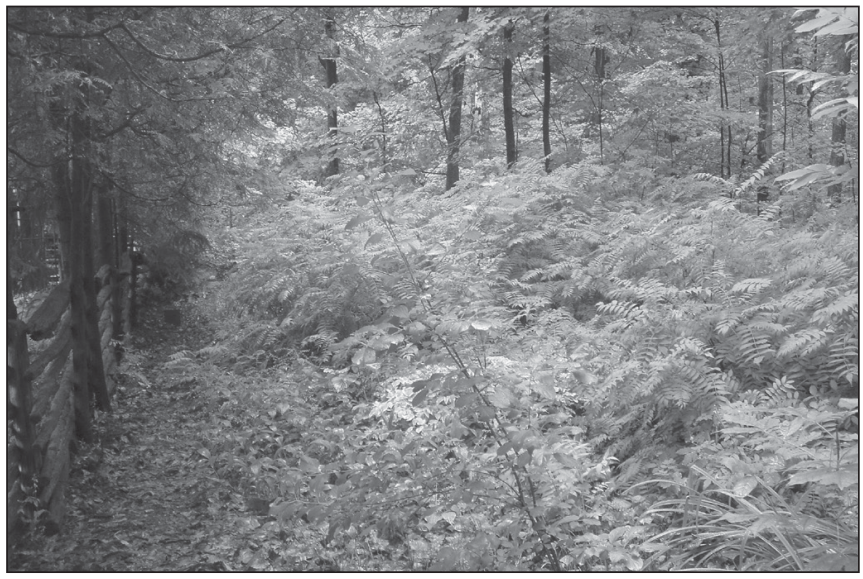

Figure 6. False spirea (Sorvaria sorbifolia) planted in the forest edge by a resident. Photo location: Idlewood Park, Kitchener.

Ninety-five percent of encroachment, in terms of frequency and area cover, was within $18 \mathrm{~m}$ of forest borders. Encroachment frequency and area cover was highest at the border, decreasing steeply until approximately $8 \mathrm{~m}$, and then more gradually to low intensity levels beyond $20 \mathrm{~m}$ (Figure 8).

The distribution of waste disposal, yard extension, invasive yard plants, and reaction to forest encroach-

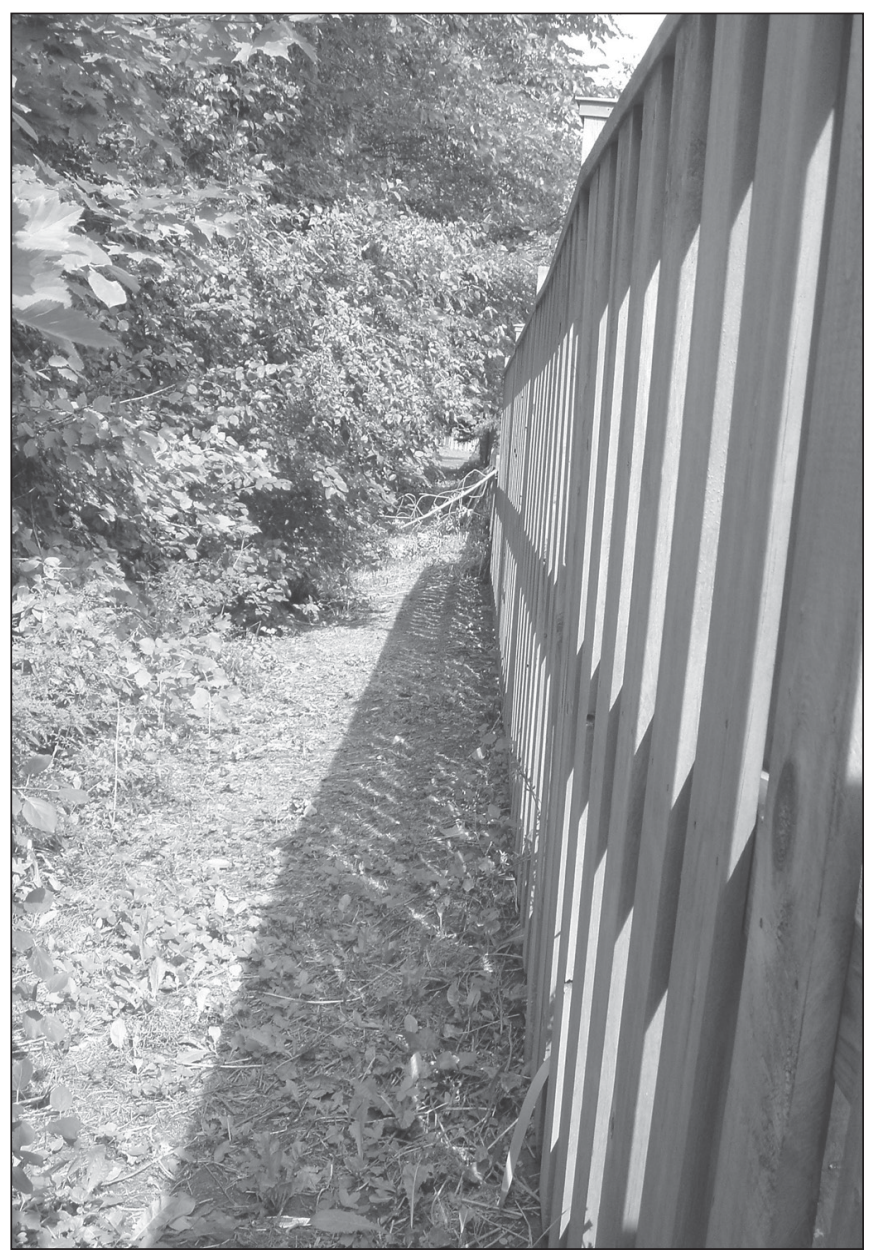

Figure 7. Forest border vegetation removal, a type of residential encroachment in response to the forest border vegetation 'encroaching' into a yard. Photo location: Creditview Park, Mississauga.

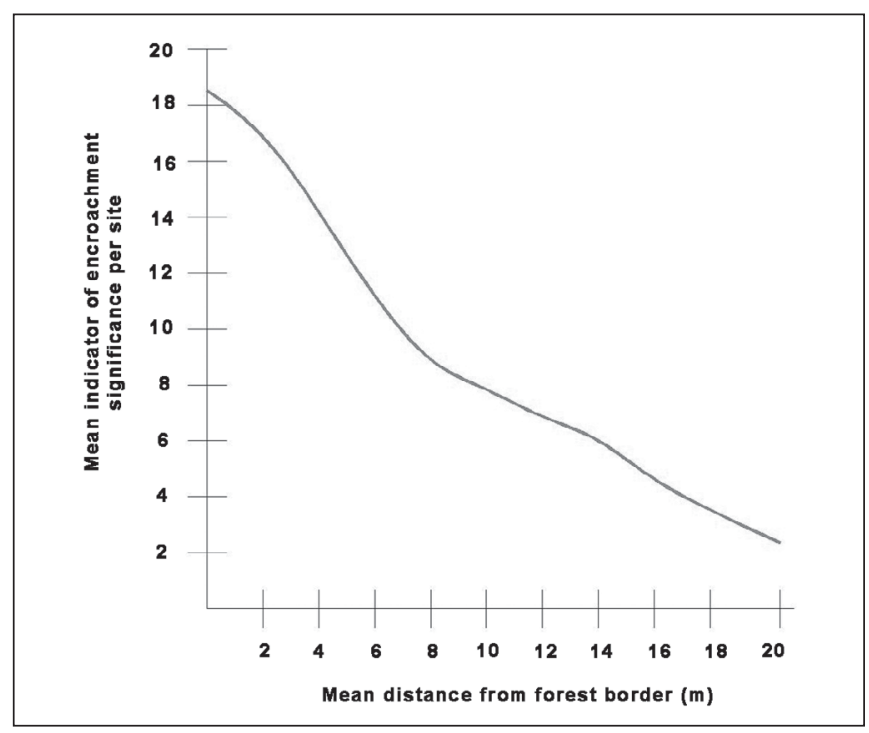

Figure 8. Mean indicator of significance of encroachment with respect to distance from forest borders. 
ment behaviors is determined by the distance from forest borders $(P<0.05)$. However, the distribution of forest recreation-related encroachments did not appear to be significantly determined by the distance from forest borders $(P>0.05)$.

Yard extension, followed by reaction to forest encroachment and invasive yard plants, were concentrated closer to forest borders than waste disposal and forest recreation encroachments (Figure 9).

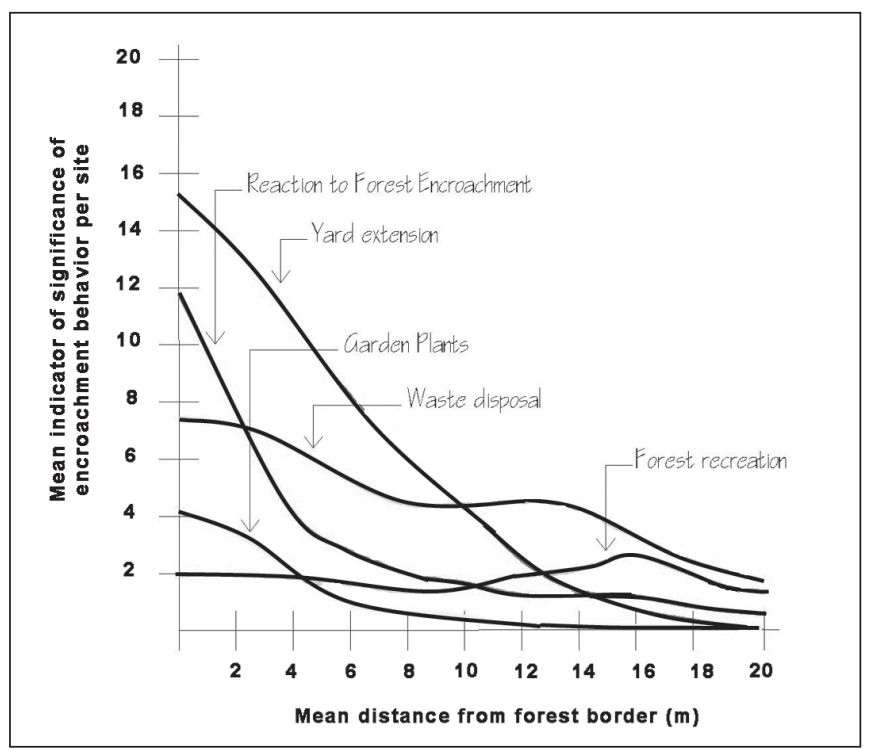

Figure 9. Mean indicators of significance for encroachment behaviors with respect to distance from forest borders

Yard extension traces had the highest mean indicator of encroachment significance (i.e., highest total area encroachment per site), relative to other encroachment behaviors. Total area cover was highest at the forest border, descending sharply within the first approximately $12 \mathrm{~m}$. The mean indicator of significance for encroachment in reaction to forest encroachment mimicked the yard extension distribution pattern; however, they covered less of the forest floor, and were distributed close to forest borders at approximately four meters.

Invasive yard plants were concentrated in the first six meters of forest borders. Site observations revealed invasions entered forest edges primarily through vegetative reproduction (Figure 10). However, residents planted some (Figure 6), and others arrived via dumping of viable invasive plant propagules in disposed waste.

The distribution of forest recreation encroachment was not as closely aligned with forest borders, and peaked farther into forest edges. Unauthorized pathways made up a majority of encroachment sampled, originating at forest borders and extending deep into the forest edge (Figure 5), while children's forts and fire pits were located at a mean distance of $16 \mathrm{~m}$.

The sampling of waste disposal revealed a 'two-humped' pattern of distribution. Although waste disposal tended to decrease in total area with distance from forest borders, they did so only gradually when compared with other behaviors. The 'two humped' pattern illustrated in Figure 9 is the result of different waste disposal behaviors associated with different boundary treatments. For example, residents having a fenced boundary tended to dump waste over their fences close to the property line

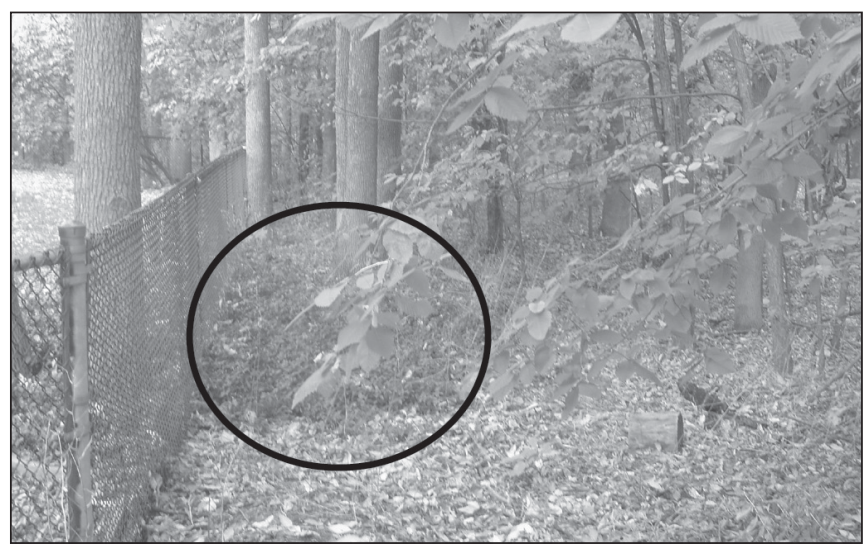

Figure 10. Periwinkle (Vinca minor) invades the forest edge via vegetative reproduction (indicated in black outline). Photo location: Deer Run Park, Mississauga.

(In Figure 9, the first spike in mean waste disposal indicator of significance.). However, when there was no boundary demarcation, when a gate was placed in a fence, or when there was a grass strip with or without pathway, residents tended to 'hide' the waste from view further into the forest edge (accounting for the second spike in waste disposal farther from forest borders). Figure 3 is an example of waste disposal under a fenced boundary treatment, while Figure 11 is an example of the second distribution pattern of waste disposal. Waste disposal occurred in association with composting bins concealed by forest vegetation.

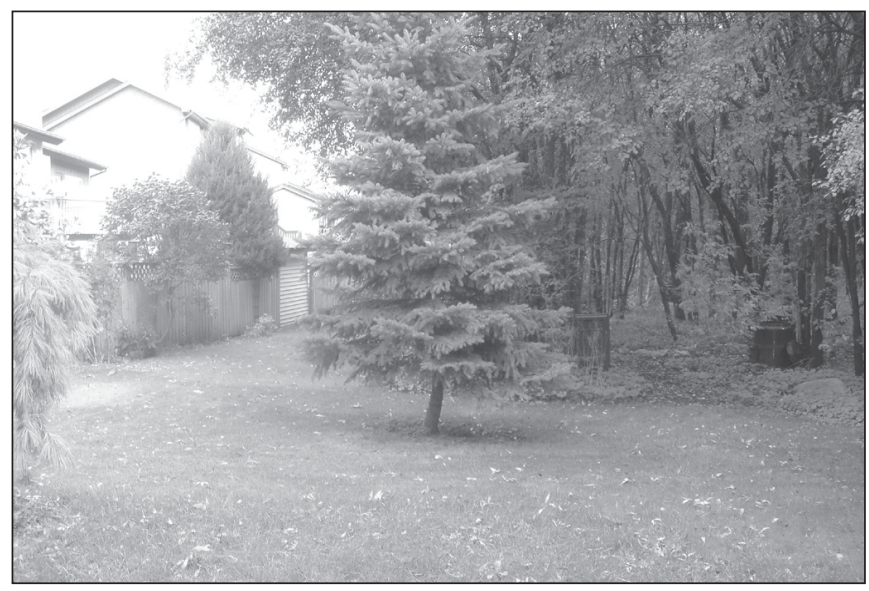

Figure 11. Dumping pattern commonly associated with a fence with gate boundary treatment. Photo location: Forfar Park, Kitchener.

\section{DISCUSSION}

According to the factors that determine the significance of recreation-related human activity impacts on forest soils, vegetation, wildlife, and recreation experience, residential encroachment represents a substantial source of degradation within municipal forest edges. Encroachment impacts are large in areal extent, intensive, and occur in highly valued ecosystems. According to boundary theory, this degraded condition of the edge suggests the health of the natural system may be at risk (Schonewald-Cox 1988).

In terms of areal extent, most impacts occur within a mean distance of $18 \mathrm{~m}$ of forest borders and cover a mean of $25 \%$ 
to $50 \%$ of the first $20 \mathrm{~m}$. This finding is confirmed by another study that found a mean extent of encroachment of $16 \mathrm{~m}$; however, encroachment can be found up to $50 \mathrm{~m}$ of forest borders (McWilliam et al. 2010). This areal extent is significant within urban forests that tend to be small in area and narrow in diameter with high edge to interior ratios. Under these conditions, encroachment impacts would cover a large proportion of the total area of the forest. This areal extent of encroachment may also extend forest edge rather than interior conditions within larger urban forests, reducing the amount of habitat available to area and disturbance-sensitive species, such as neotropical forest birds, which are uncommon within urban landscapes.

Encroachment occurs at a high intensity in Ontario. Occurring frequently among edge residents, in 99\% of sites. Encroachment also occurs frequently within the forest behind each residence, with a mean frequency of 23 traces (evidence of encroachment within quadrats) per residence. Encroachment types and behaviors sampled suggest significant ecological impacts. For example, encroachment related to waste disposal, forest recreation, response to forest encroachment, and invasive yard plant extensions, often result in trampling impacts on soil structure and fertility (Malmivaara-Lamsa and Fritze 2003), the loss and degradation of native vegetation communities (Florgard 2000; Murphy 2006), and may result in losses in local or regional native wildlife biodiversity (Friesen et al. 1995; Jokimaki and Huhta 2000). Their associated social and economic impacts may be even more significant to human communities. For example, yard extensions result in the loss of publicly-owned forest into private ownership, and the ecosystem services forests provide. Equitable access to these community resources is undermined with edge residents gaining greater access and use than residents living farther away. Waste disposal activities erode the aesthetics and recreational experience of the forest (Lynn and Brown 2003). Furthermore, these activities will lead to significant economic costs to communities when municipalities increase active management resources to reduce impacts to levels acceptable to their communities.

Field observations and conversations with municipal staff suggested many encroachment impacts remain in place over long periods. For example, conversations with municipal bylaw enforcement officers revealed many encroachments were difficult to remove once in place, particularly yard extensions (McWilliam 2009).

Encroachment is also occurring within ecosystems that have low resistance and resiliency with respect to human activity impacts. Deciduous forests are among the least resilient to encroachment because of their sensitive ground floras (Kuss 1986; Kuss and Hall 1991). Furthermore, encroachment activities are concentrated within the growing season when both vegetation and reproducing wildlife are at their most sensitive (Cole 2003).

In forests adjacent to existing development, boundary treatments that reduce encroachment, active management (e.g., bylaw enforcement and monitoring), and resident education, could be implemented more frequently. In newly developing areas, effective land use planning that reduces the area of encroachment at coarse spatial scales could significantly reduce the need for expensive boundary structures and active management regimes, and may be more effective in protecting the features and functions of natural systems in the long term. Effective planning measures could include: 1) protection of less vulnerable forests (e.g., larger in area with lower edge to interior ratios); 2) placing single-family residential subdivisions adjacent to less sensitive, or more resilient, natural systems; 3 ) altering the configuration of residential subdivisions to reduce the length of forest edge exposed to encroachment, or 4) encouraging adjacent land uses more supportive to forested natural system features and functions. Further research is required to test the efficacy of these alternative strategies for limiting the area of encroachment impacts following development.

\section{LITERATURE CITED}

Braun-Blanquet, J. 1932. Plant Sociology: the Study of Plant Communities. McGraw-Hill, New York.

Brown, R.D., and T.J. Gillespie. 1995. Microclimatic Landscape Design. John Wiley \& Sons, New York.

Cole, D.N. 1987. Effects of three seasons of experimental trampling on five montane forest communities and a grassland in western Montana, USA. Biological Conservation 40:219-244.

Cole, D. N., and J.L. Marion 1988. Recreation impacts in some riparian forests of the eastern United States. Environmental Management 12:99-107.

Cole, D.N. 2003. Backcountry impact management: lessons from research. Trends 31(3):10-14.

Correll, D.L. 1999. Vegetated stream riparian zones: their effects on stream nutrients, sediments and toxic substances. Report of Smithsonian Environmental Research Center. Maryland, USA. Accessed October 18, 2002. <http://www.serc.si.edu/SERC_web_html/pub_ ripzone.htm>

Florgard, C. 2000. Long-term changes in indigenous vegetation preserved in urban areas. Landscape and Urban Planning 52:101-116.

Friesen, L.E., P.F.J. Eagles, and R.J. MacKay. 1995. Effect of residential development on forest-dwelling neotropical migrant songbirds. Conservation Biology 9(6):1408-1414.

Jokimaki, J., and E. Huhta. 2000. Artificial nest predation and abundance of birds along an urban gradient. Condor 102(4):838-847.

Kaplan, S. 1995. The urban forest as a source of psychological well-being, In: G.A. Bradley (Ed.). Urban Forest Landscapes: Integrating Multidisciplinary Perspectives. University of Washington Press, Seattle.

Kent, M., and P. Coker. 1992. The description of vegetation in the field, pp. 20-38. In: Vegetation Description and Analysis: A Practical Approach. Belhaven Press, London.

Kuss, F.R. 1986. A review of major factors influencing plant responses to recreation impacts. Environmental Management 10:637-650.

Kuss, F.R., and C.N. Hall. 1991. Ground flora trampling studies: five years after closure. Environmental Management 15:715-727.

Lynn, N., and R.D. Brown. 2003. Effects of recreational use impacts on hiking experiences in natural areas. Landscape and Urban Planning 64:77-87.

Malmivaara-Lamsa, M., and H. Fritze. 2003. Effects of wear and above ground forest site type characteristics on the soil microbial community structure in an urban setting. Plant and Soil 256:187-203.

Matlack, G.R. 1993. Sociological edge effects: spatial distribution of human impact in suburban forest fragments. Environmental Management 17:829-835.

McWilliam, W.J. 2009. The Housing/Forest Interface: Structural Approaches for Protecting Suburban Natural Areas Post Development. VDM Verlag Dr. Muller, Saarbrucken, Germany.

McWilliam, W.J., P. Eagles, M. Seasons, and R. Brown. 2010. The housing/forest interface: testing structural approaches for protecting suburban natural systems following development. Urban Forestry and Urban Greening 9:149-159. 
Murphy, S.D. 2006. Why micro-scale urban ecology matters, pp. 379392. In: T. Bunting and P. Filion (Eds.). Canadian Cities in Transition: From the Local to the Global, 3rd. Edition. Oxford University Press, Don Mills, Ontario.

Nowak, D.J., and D.E. Crane. 2002. Carbon storage and sequestration by urban trees in the USA. Environmental Pollution 116:381-389.

Ontario Ministry of Natural Resources. 2002. Natural resources and values information system (computer file). Ontario Ministry of Natural Resources, Toronto, Ontario.

Schonewald-Cox, C.M. 1988. Boundaries in the protection of nature reserves. Bioscience 38(7):480-486.

Scott, K. I., J.R. Simpson, and E.G. McPherson. 1999. Effects of tree cover on parking lot microclimate and vehicle emissions, Journal of Arboriculture 25(3):129-142.

Taylor, G. 1992. A study of encroachment into and around selected urban ESPAs. Region of Waterloo Ecological and Environmental Advisory Committee. Region of Waterloo.

\section{Wendy McWilliam (corresponding author) \\ McWilliam Environmental Planning and Design \\ 133 Glasgow St. N. \\ Guelph, Ontario N1H4W5 \\ Canada}

\section{Paul Eagles \\ University of Waterloo \\ Recreation and Leisure Studies \\ Waterloo, Ontario \\ Canada}

\section{Mark Seasons \\ University of Waterloo \\ School of Planning \\ Waterloo, Ontario \\ Canada}

Robert Brown

University of Guelph

Landscape Architecture

Guelph, Ontario

Canada

Résumé. Les forêts urbaines ont des fonctions essentielles aux niveaux social, écologique et économique en support à leur communauté; cependant, les enquêtes indiquent que les résidants adjacents mènent des activités à l'intérieur de leur propriété et en bordure des forêts publiques qui dégradent ces systèmes. Les gouvernements locaux comptent sur la surveillance passive des limites ainsi que la gestion active pour limiter ces impacts. L'empiètement produit des impacts variés le long de cette limite; néanmoins, aucune donnée n'est disponible quant à savoir si cet empiètement représente une source substantielle de dégradation dans les forêts municipales de l'Ontario au Canada. Pour évaluer cela, les impacts en fonction du pourcentage de superficie empiétée de 186 résidences au sein de 40 forêts de six municipalités ontariennes ont été évalués. Les résultats indiquent que la dégradation résultant de l'empiètement était sub- stantielle. L'empiètement survenait au sein des écosystèmes de grandes valeurs et fragiles et aussi durant les périodes plus délicates. Ceci était particulièrement prévalent et occupait une proportion substantielle de la lisière des forêts. Certains comportements liés à l'empiètement étaient particulièrement dommageables, ce qui résultait en perte significative de superficie forestière au profit d'usages résidentiels. De plus, les empiètements demeuraient présents sur de longues périodes. La petite superficie et les formes convolutées des forêts urbaines rendent ces dernières vulnérables à ces impacts. Les stratégies municipales qui prévalent sont insuffisantes pour protéger ces systèmes de l'empiètement. Afin d'assurer leur protection à long terme, les municipalités et leur communautés ont besoin d'accroître substantiellement leur implication et les ressources pour contrer l'empiètement.

Zusammenfassung. Urbane Wälder liefern bedeutende soziale, ökologische und ökonomische Funktionen zur Unterstützung ihrer Kommunen, dennoch zeigen Umfragen, daß die Anlieger innerhalb ihrer Grundstücke und im Bereich der angrenzenden Wälder Eingriffe vornehmem, die diesen Funktionen entgegen wirken. Lokale Verwaltungen sind abhängig von einer passiven Grenzbewirtschaftung und/oder aktivem Management, um äußere Einflüsse zu limitieren. Diese Eingriffe durch Anlieger führen zu verschiedenen Grenzgestaltungsmaßnahmen. Dennoch ist nicht bekannt, ob die Eingriffe eine substantielle Quelle der Forstdegradierung in Ontario, Canada darstellen. Um das zu bewerten, wurden in 40 kommunalen Wäldern in Süd-Ontario in der Nahcbarschaft von 186 Anwesen die von Eingriffen betroffenen Flächen untersucht Die Ergebnisse zeigen, daß eine Degradierung durch Eingriffe deutlich wurde. Die Eingriffe hatten in den hoch bewerteten in sensiblen Ökosystemen sowie in sensiblen Zeitperiodengefunden. Das war hochgradig relevant und betraf einen Großteil der Waldrandflächen. Einiges Verhalten war besonders zerstörerrisch und resulierte in einem deutlichen Flächenverlust des Waldes zugunsten der Landnutzung durch den Anlieger. Darüberhinaus blieben diese Eingriffe längere Zeit bestehen. Die kleinen Flächengrößen und die unregelmässigen Formen der urbanen Waldflächen macht sie besonders empfindlich für solche Eingriffe von außen. Die bestehenden kommunalen Strategien zum Schutz der Waldflächen zeigen sich wirkungslos gegenüber solchen Eingriffen. Um einen langfristigen Schutz zu sichern, müssen Kommunen und Verwaltungen ihr Engagement und Mitteleinsatz verstärken, um diesen Eingriffen entgegenzuwirken

Resumen. Los bosques urbanos proveen funciones sociales, ecológicas y económicas en apoyo de sus comunidades; sin embargo, las encuestas indican que la conducta de los residentes adyacentes dentro de sus jardines y en los bosques públicos cercanos degradan estos sistemas. Los gobiernos locales confían en el manejo activo y pasivo para limitar impactos. Sin embargo, no se conoce si las infracciones representan una fuente sustancial de degradación dentro de los bosques municipales de Ontario, Canadá. Para evaluar esto, se midió el porcentaje de cobertura de los impactos adyacentes a 186 hogares dentro de 40 bosques de municipalidades del sureste de Ontario. Los resultados indican que la degradación resultante fue sustancial; las intromisiones ocurrieron en ecosistemas altamente valiosos y sensibles, y durante períodos de tiempo importantes. Esto fue altamente activo y cubrió una proporción sustancial del bosque. Algunos comportamientos invasivos fueron particularmente dañinos, resultando en la pérdida de áreas de bosques significantes en terrenos de uso residencial. Sin embargo, las intromisiones permanecieron por largos períodos. Los tamaños pequeños y las formas complicadas de los bosques urbanos los dejaron vulnerables a esos impactos. Las estrategias municipales comunes son insuficientes para proteger estos sistemas de los impactos. Para asegurar su protección a largo plazo, las municipalidades y sus comunidades necesitan incrementar sustancialmente sus recursos para dirigir el impacto. 